\title{
Bifidobacterium inopinatum sp. nov. and Bifidobacterium denticolens sp. nov., Two New Species Isolated from Human Dental Caries
}

\author{
F. CROCIANI, ${ }^{1 *}$ B. BIAVATI,${ }^{2}$ A. ALESSANDRINI, ${ }^{2}$ C. CHIARINI, ${ }^{2}$ AND V. SCARDOVI ${ }^{2} \dagger$ \\ Istituto di Citomorfologia Normale e Patologica, Consiglio Nazionale della Ricerche, Sezione di Bologna, Istituto \\ Codivilla Putti, 40136 Bologna, ${ }^{1}$ and Istituto di Microbiologia Agraria e Tecnica, 40126 Bologna, ${ }^{2}$ Italy
}

\begin{abstract}
In a previous investigation of bifidobacteria isolated from human dental caries (V. Scardovi and F. Crociani, Int. J. Syst. Bacteriol. 24:6-20, 1974), 40 strains were assigned to the new species Bifidobacterium dentium. In this study we examined 70 new strains of bifidobacteria isolated from dental caries. The morphological characteristics, biochemical reactions, fermentation patterns, end products from glucose metabolism, protein electrophoretic patterns, levels of DNA hybridization, and DNA G + C contents of these organisms revealed that they belong to three different taxa. One of these taxa was identified as $B$. dentium. The other two are described as the following new Bifidobacterium species in this paper: Bifidobacterium inopinatum (type strain, DSM 10107) and Bifidobacterium denticolens (type strain, DSM 10105). The two new species differ from other Bifidobacterium species in their morphological characteristics (especially $B$. inopinatum, with its very small coccoid cells), in their carbohydrate fermentation patterns (most strains ferment dextran, and $B$. inopinatum does not ferment galactose), and in their DNA base compositions (especially $B$. inopinatum).
\end{abstract}

The first report of isolation of bacteria identified as bifidobacteria from the mouths of infants and from dental caries dates back to 1915 (4); subsequently, some strains that are phenotypically related to Bifidobacterium adolescentis were isolated from oral cavities $(1,15)$ and gingival crevices $(13)$. Bifidobacteria have also been isolated from saliva (18) and from dental plaque, in which they accounted for $6 \%$ of all isolates (12). In 1974 Scardovi and Crociani (20) identified 40 similar strains of bifidobacteria that were isolated from dental caries as organisms that were genetically unrelated to any other Bifidobacterium species, and those strains were assigned to the new species Bifidobacterium dentium. This species proved to be synonymous with the species containing strains isolated from human oral cavities previously studied by Beerens et al. (1). The results of a polyacrylamide gel electrophoresis study (3) demonstrated that the species previously known as "Actinomyces eriksonii" (8) and subsequently designated "Bifidobacterium eriksonii" by Holdeman and Moore (10) was very similar to $B$. dentium and that " $B$. eriksonii" was a synonym of $B$. dentium. However, the name $B$. dentium has been retained since neither "A. eriksonii" nor "B. eriksonii" appeared on the Approved Lists of Bacterial Names (25) and thus these names have no taxonomic standing and cannot be considered earlier synonyms of $B$. dentium. Recently (6), this species was shown to be the only Bifidobacterium species which ferments guar and locust bean gums.

Since $B$. dentium was first characterized in 1974 , we decided to try to obtain new isolates from the same habitat. The results of our study confirmed that $B$. dentium was present in dental caries along with two groups of strains that could be placed in the genus Bifidobacterium on the basis of the presence of fructose-6-phosphate phosphoketolase, the key enzyme of the glucose catabolic pathway in this genus $(7,21)$, and the pres-

* Corresponding author. Mailing address: Istituto di Citomorfologia Normale e Patologica, CNR, Sezione di Bologna, Istituto Codivilla Putti, Via di Barbiano 1/10, 40136 Bologna, Italy. Phone: 39-51351606. Fax: 39-51-351600.

$†$ Vittorio Scardovi died on 11 August 1995, after submission of the manuscript. ence of acetic and lactic acids as end products of glucose fermentation. The results of DNA relatedness, physiological, and metabolic studies justified recognition of these two groups as new Bifidobacterium species. These two species had the ability to degrade dextran, a unique characteristic among the 29 species of the genus Bifidobacterium (6). In this study we investigated the phenotypic characteristics and genetic relationships of the two groups of dextran-degrading bifidobacteria isolated from dental caries in order to determine their taxonomic positions. A comparative study in which $B$. dentium strains isolated from dental caries were included was also performed.

\section{MATERIALS AND METHODS}

Bacterial strains and growth conditions. The strains which we studied and their sources are listed in Table 1 . The human dental caries samples were collected at a dental surgery, immediately transferred to our laboratory, and mixed with saline. The strains were isolated on anaerobic plates containing Trypticase-Phytone-yeast extract (TPY) agar (19). All isolates were grown anaerobically in GasPak jars (BBL) at $37^{\circ} \mathrm{C}$ in TPY broth and were maintained freeze-dried and at $-135^{\circ} \mathrm{C}$ as suspensions in skim milk.

Characterization of strains. To determine sugar fermentation patterns, TPY broth was used without glucose but was supplemented with bromcresol purple $(30 \mathrm{mg} / \mathrm{l}$ ) as a $\mathrm{pH}$ indicator, the $\mathrm{pH}$ of the medium was adjusted to 7.2 to 7.5 , and the medium was dispensed into test tubes $(2 \mathrm{ml}$ per tube). Most of the 52 substrates tested were added at a concentration of $0.5 \%(\mathrm{wt} / \mathrm{vol})$; ovomucoid, bovine submaxillary mucin, and porcine gastric mucin were added at a concentration of $1 \%$ (wt/vol). Most of the substrate were heated twice at $100^{\circ} \mathrm{C}$ in the basal medium; the exceptions were pentoses, D-galactosamine, D-glucosamine, heparin, ovomucoid, and pectin, which were added to autoclaved medium as filter-sterilized solutions. Growth, color changes, and $\mathrm{pH}$ values were recorded after 7 days of anaerobic incubation in GasPak jars at $37^{\circ} \mathrm{C}$. The methods used to study other phenotypic characteristics of the strains have been described previously (20).

Tomato juice agar without a carbon source and Mann-Rogosa-Sharpe media were also used to evaluate changes in cell morphology.

The oxygen relationships and the $\mathrm{CO}_{2}$ requirement of the strains were studied by observing growth on slants incubated in air, in nitrogen gas, in $10 \% \mathrm{CO}_{2}$ in nitrogen gas, and in air containing $10 \% \mathrm{CO}_{2}$. The temperature relationships were determined with the temperature gradient incubator described by Oppenheimer and Drost-Hansen (17). Media having various $\mathrm{pH}$ values were obtained by adding $20 \%$ lactic acid (to obtain $\mathrm{pH}$ values ranging from 7 to 4 ) and $2 \mathrm{M}$ $N$-tris(hydroxymethyl)-aminomethane (to obtain $\mathrm{pH}$ values ranging from 7 to 9 ) to sterilized TPY medium. For spectrophotometry media were aseptically dispensed in an anaerobic chamber (Coy) into assay tubes closed with butyl rubber 
TABLE 1. Strains used

\begin{tabular}{|c|c|c|}
\hline Strain(s) & Source $^{a}$ & Source of isolation \\
\hline $\begin{array}{l}\text { Bifidobacterium inopinatum B3109 }\left(=\mathrm{DSM} 10107^{\mathrm{T}}\right), \mathrm{B} 3002, \mathrm{~B} 3003, \mathrm{~B} 3008, \mathrm{~B} 3010, \mathrm{~B} 3012, \\
\mathrm{~B} 3014, \mathrm{~B} 3016, \mathrm{~B} 3055, \mathrm{~B} 3056, \mathrm{~B} 3059, \mathrm{~B} 3062, \mathrm{~B} 3066, \mathrm{~B} 3067, \mathrm{~B} 3070, \mathrm{~B} 3073, \mathrm{~B} 3074, \mathrm{~B} 3080, \\
\mathrm{~B} 3081, \mathrm{~B} 3082, \mathrm{~B} 3083, \mathrm{~B} 3085, \mathrm{~B} 3086, \mathrm{~B} 3093, \mathrm{~B} 3094, \mathrm{~B} 3096, \mathrm{~B} 3099, \mathrm{~B} 3100, \mathrm{~B} 3101, \mathrm{~B} 3103, \\
\mathrm{~B} 3104, \text { and B3105 }\end{array}$ & Our collection & Human dental caries \\
\hline $\begin{array}{l}\text { B. denticolens } \mathrm{B} 3028^{\mathrm{T}}\left(=\mathrm{DSM} 10105^{\mathrm{T}}\right), \mathrm{B} 3005, \mathrm{~B} 3006, \mathrm{~B} 3007, \mathrm{~B} 3029, \mathrm{~B} 3030, \mathrm{~B} 3031, \\
\text { B3032, B3047, B3049, B3050, B3087, B3088, B3090, B3091, and B3107 }\end{array}$ & Our collection & Human dental caries \\
\hline B. adolescentis $\mathrm{E} 194 \mathrm{a}^{\mathrm{T}}\left(=\mathrm{ATCC} 15703^{\mathrm{T}}\right)$ & Reuter & Intestine of adult \\
\hline B. angulatum $\mathrm{B} 677^{\mathrm{T}}\left(=\mathrm{ATCC} 27535^{\mathrm{T}}\right)$ & Our collection & Human adult feces \\
\hline B. animalis $\mathrm{R} 101-8^{\mathrm{T}}\left(=\right.$ ATCC $\left.25527^{\mathrm{T}}\right)$ & Mitsuoka & Rat feces \\
\hline B. asteroides $\mathrm{C} 51^{\mathrm{T}}\left(=\operatorname{ATCC} 25910^{\mathrm{T}}\right)$ & Our collection & Apis mellifera \\
\hline B. bifidum $\mathrm{Ti}^{\mathrm{T}}\left(=\mathrm{DSM} 20456^{\mathrm{T}}\right)$ & DSM & Human infant feces \\
\hline B. boum $\mathrm{Ru} 917^{\mathrm{T}}\left(=\mathrm{ATCC} 27917^{\mathrm{T}}\right)$ & Our collection & Bovine rumen \\
\hline B. breve $\mathrm{S}^{\mathrm{T}}\left(=\mathrm{ATCC} 15700^{\mathrm{T}}\right)$ & Reuter & Human infant feces \\
\hline B. catenulatum $\mathrm{B} 669^{\mathrm{T}}\left(=\right.$ ATCC $\left.27539^{\mathrm{T}}\right)$ & Our collection & Human adult feces \\
\hline B. choerinum Su $806^{\mathrm{T}}\left(=\right.$ ATCC $\left.27686^{\mathrm{T}}\right)$ & Our collection & Pig feces \\
\hline B. coryneforme $\mathrm{C} 215^{\mathrm{T}}\left(=\operatorname{ATCC} 25911^{\mathrm{T}}\right)$ & Our collection & Apis mellifera \\
\hline B. cuniculi $\operatorname{Ra} 93^{\mathrm{T}}\left(=\operatorname{ATCC} 27916^{\mathrm{T}}\right)$ & Our collection & Rabbit feces \\
\hline B. dentium B764 $\left(=\right.$ ATCC $\left.27534^{\mathrm{T}}\right)$ & Our collection & Human dental caries \\
\hline B. gallicum $\mathrm{P}^{\mathrm{T}}\left(=\mathrm{DSM} 20093^{\mathrm{T}}\right)$ & DSM & Human feces \\
\hline B. gallinarum $\mathrm{CH} 206-5^{\mathrm{T}}\left(=\right.$ ATCC $\left.33777^{\mathrm{T}}\right)$ & ATCC & Chicken cecum \\
\hline B. globosum $\mathrm{Ru} 230^{\mathrm{T}}\left(=\right.$ ATCC $\left.25864^{\mathrm{T}}\right)$ & Our collection & Bovine rumen \\
\hline B. indicum $\mathrm{C} 410^{\mathrm{T}}\left(=\operatorname{ATCC} 25912^{\mathrm{T}}\right)$ & Our collection & Apis cerana \\
\hline B. infantis $\mathrm{S} 12^{\mathrm{T}}\left(=\mathrm{ATCC} 15697^{\mathrm{T}}\right)$ & Reuter & Human infant feces \\
\hline B. longum E194b $\left(=\right.$ ATCC $\left.15707^{\mathrm{T}}\right)$ & Reuter & Human adult feces \\
\hline B. magnum $\mathrm{Ra}^{\mathrm{T}}\left(=\right.$ ATCC $\left.27540^{\mathrm{T}}\right)$ & Our collection & Rabbit feces \\
\hline B. merycicum Ru915B ${ }^{\mathrm{T}}\left(=\right.$ ATCC $\left.49390^{\mathrm{T}}\right)$ & Our collection & Bovine rumen \\
\hline B. minimum $\mathrm{F} 392^{\mathrm{T}}\left(=\right.$ ATCC $\left.27538^{\mathrm{T}}\right)$ & Our collection & Sewage \\
\hline B. pseudocatenulatum B1279 $\left(=\right.$ ATCC $\left.27919^{\mathrm{T}}\right)$ & Our collection & Human infant feces \\
\hline B. pseudolongum PNC-2-9G ${ }^{\mathrm{T}}\left(=\right.$ ATCC $\left.25526^{\mathrm{T}}\right)$ & Mitsuoka & Pig feces \\
\hline B. pullorum $\mathrm{P} 145^{\mathrm{T}}\left(=\right.$ ATCC $\left.27685^{\mathrm{T}}\right)$ & Our collection & Chicken feces \\
\hline B. ruminantium Ru687 $7^{\mathrm{T}}\left(=\right.$ ATCC $\left.49390^{\mathrm{T}}\right)$ & Our collection & Bovine rumen \\
\hline B. saeculare Ral61 ${ }^{\mathrm{T}}\left(=\right.$ ATCC $\left.49392^{\mathrm{T}}\right)$ & Our collection & Rabbit feces \\
\hline B. subtile $\mathrm{F} 395^{\mathrm{T}}\left(=\right.$ ATCC $\left.27537^{\mathrm{T}}\right)$ & Our collection & Sewage \\
\hline B. suis $\mathrm{Su} 859^{\mathrm{T}}\left(=\right.$ ATCC $\left.27533^{\mathrm{T}}\right)$ & Our collection & Pig feces \\
\hline B. thermophilum $\mathrm{P} 2-91^{\mathrm{T}}\left(=\right.$ ATCC $\left.25525^{\mathrm{T}}\right)$ & Mitsuoka & Swine feces \\
\hline Gardnerella vaginalis $594^{\mathrm{T}}\left(=\operatorname{DSM} 4944^{\mathrm{T}}\right)$ & DSM & Vaginal secretions \\
\hline
\end{tabular}

a DSM, Deutsche Sammlung von Mikroorganismen und Zellkulturen GmbH; ATCC, American Type Culture Collection.

stoppers. Inoculation was carried out under an $\mathrm{N}_{2}-\mathrm{CO}_{2}(80: 20)$ atmosphere by using $0.1 \mathrm{ml}$ of a 24-h anaerobic culture in TPY liquid medium per tube, and the resulting preparations were incubated at $37^{\circ} \mathrm{C}$ for $24 \mathrm{~h}$. We used two uninoculated tubes for each $\mathrm{pH}$ as real controls of the initial $\mathrm{pH}$ and for subsequent evaluation of the effect of dissolved $\mathrm{CO}_{2}$ on the media at various $\mathrm{pH}$ values. All of the experiments were performed in duplicate. Growth was measured by repeatedly determining the optical density at $600 \mathrm{~nm}$ with a Spectronic 20 spectrophotometer (Bausch \& Lomb, Inc.). The final $\mathrm{pH}$ values were also determined.

Nutritional needs were determined in the synthetic medium described previously (22). The synthetic medium was supplemented with various substances (amino acids, vitamins, nitrogen bases, mineral salts, etc.), prereduced in hermetically sealed Pyrex bottles in an anaerobic chamber, and distributed into $10-\mathrm{ml}$ assay tubes for spectrophotometry. The tubes were closed with butyl rubber stoppers, heated twice at $100^{\circ} \mathrm{C}$ for $30 \mathrm{~min}$, and inoculated under an $\mathrm{N}_{2}-\mathrm{CO}_{2}(80: 20)$ atmosphere with $0.1-\mathrm{ml}$ portions of an $\mathrm{NaCl}$ solution suspension of washed cells obtained from a $24-\mathrm{h}$ TPY anaerobic culture. The tubes were incubated at $37^{\circ} \mathrm{C}$ for 4 to 5 days; growth was determined spectrophotometrically and by determining the final $\mathrm{pH}$. We used TPY medium and synthetic medium with no additions for positive and negative growth controls, respectively. An uninoculated tube of each medium was used as a $\mathrm{pH}$ and optical density control. All of the experiments were performed in duplicate. The kinds of acids produced during glucose fermentation and the ratios of acetic acid to lactic acid were determined by the method of Holdeman et al. (9). The lactic acid configuration was determined by using the test combination for determination of $\mathrm{D}$ - and $\mathrm{L}$-lactic acids (Boehringer-Mannheim). The fructose-6-phosphate phosphoketolase contents of cell extracts were determined as described by Schramm et al. (23). Polyacrylamide gel electrophoresis of soluble proteins was performed as described previously (3).

DNA relatedness, DNA base composition, and plasmid analyses. Levels of DNA-DNA relatedness were determined by a previously described procedure (20). DNA isolated by the procedure of Marmur (14) was fixed on Sartorius type SM 11306 nitrocellulose membrane filters and hybridized by using a procedure in which the single-point competition reaction was used. The reference strains were hybridized three times with each competitor strain. In order to minimize the variability of the data, the labeled DNAs were obtained from the same batch of cells of each reference strain and the hybridization filters were obtained from the same mother filter.

DNA base compositions ( $\mathrm{G}+\mathrm{C}$ contents) were calculated from melting temperatures determined with a Response series UV-visible spectrophotometer equipped with a Response II thermal programmer. Escherichia coli K-12 DNA was used as the standard. The plasmid analyses were performed by previously described methods (24).

\section{RESULTS AND DISCUSSION}

A total of 70 strains were isolated from 15 samples of dental caries; many of these strains had the typical bifidobacterial morphology, while others had an unexpected morphology characterized by very small coccoid cells, which gave rise to the designation "inopinatum group." If it had not been for the extremely rare occurrence of longer irregular cells, these isolates probably would have been discarded. All of the isolates were anaerobic and gram positive, contained fructose-6-phosphate phosphoketolase, produced acetic and lactic acids as end products of glucose metabolism, and therefore were considered members of the genus Bifidobacterium. On the basis of the morphological features of these organisms and the electrophoretic patterns of their soluble proteins, we distinguished three main groups, which were investigated in detail. The results of our analyses of phenetic characteristics, levels of DNA 
TABLE 2. Fermentative characteristics of two new Bifidobacterium species isolated from dental caries ${ }^{a}$

\begin{tabular}{lcccc}
\hline & \multicolumn{4}{c}{ Production of acid by ${ }^{b}$ : } \\
\cline { 2 - 5 } \multicolumn{1}{c}{ Compound } & $\begin{array}{c}\text { B. inopinatum } \\
\text { (31 strains) }\end{array}$ & $\begin{array}{c}\text { B. inopinatum } \\
\text { B3109 }\end{array}$ & $\begin{array}{c}\text { B. denticolens } \\
(15 \text { strains })\end{array}$ & $\begin{array}{c}\text { B. denticolens } \\
\text { B3028 }^{\mathrm{T}}\end{array}$ \\
\hline L-Arabinose & - & - & $+(8)$ & + \\
D-Xylose & + & + & - & - \\
Galactose & - & - & + & + \\
D-Glucuronate & $-(5)$ & - & - & - \\
D-Glucosamine & - & - & $+(8)$ & + \\
Trehalose & - & - & $-(4)$ & - \\
Melibiose & $+(3)$ & + & + & + \\
Lactose & $+(7)$ & + & + & + \\
Cellobiose & - & - & + & + \\
Melezitose & $-(13)$ & - & - & + \\
Raffinose & $+(3)$ & + & + & + \\
Inulin & $-(10)$ & - & + & + \\
Dextran & $+(1)$ & + & $+(4)$ & + \\
Salicin & $+(4)$ & + & + & + \\
\hline
\end{tabular}

"All strains fermented ribose, glucose, fructose, sucrose, maltose, dextrin, starch, amylose, and amylopectin. None of the strains fermented L-rhamnose, mannose, $\alpha$-D-galacturonate, D-fucose, L-fucose, D-galactosamine, gluconate, lactate, xylan, polygalacturonate, alginate, arabinogalactan, pectin, laminarin, mannitol, D-glucitol, glycerol, hyaluronate, heparin, chondroitin sulfate, ovomucoid, bovine submaxillary mucin, porcine gastric mucin, gum arabic, gum ghatti, gum guar, gum locust bean, gum karaya, and gum tragacanth.

${ }^{b}-$, negative reaction; + , positive reaction. The numbers in parentheses are the numbers of strains that exhibited the other reaction.

relatedness, and DNA base compositions $(\mathrm{G}+\mathrm{C}$ contents $)$ led us to place 32 of the isolates (obtained from eight specimens) in the inopinatum group, 16 of the isolates (obtained from five specimens) in the "denticolens group," and 22 strains (obtained from seven specimens) in the previously described species $B$. dentium.

Morphology. The cells of the strains belonging to the inopinatum group were very small and coccoid when they were grown in TPY liquid medium, and they occurred singly or in pairs; rarely short irregularly shaped rods were observed (Fig. 1a). The sediment in liquid cultures was homogeneous and could be easily dispersed. There were two different types of colonies on TPY agar, transparent (T) and opaque (O) (as determined by using different types of illumination with a Zeiss Tessovar stereomicroscope) (Fig. 1). The two types of colonies were made up of cells that differed significantly in morphology and size; the cells obtained from the T colonies (e.g., strain B $3109 / 8$ cells) had species-specific shapes and dimensions (Fig. 11), whereas the cells obtained from the O colonies (e.g., strain B 3109/1 cells) were mostly rod shaped, longer, and slightly irregular or rarely club shaped (Fig. 1g). In liquid cultures incubated in the presence of $10 \%$ oxygen, the cells obtained from $\mathrm{O}$ or $\mathrm{T}$ colonies were longer and flexuous with enlarged ends or rarely branched (Fig. $1 \mathrm{~h}$ and i), which is consistent with the classic morphology of bifidobacteria. Under certain nutritional conditions the cells could change (Fig. $1 \mathrm{~b}$ through $\mathrm{f}, \mathrm{m}$, and $\mathrm{n}$ ). Cultures of strains belonging to the denticolens group grown in TPY liquid medium always had clear supernatants with compact sediment in clumps that could not be dispersed with vigorous swirling and contained small slender rods that occasionally were arranged in a V shape (Fig. 2a, c, i, and $\mathrm{m}$ ). Different strains had different morphologies under the same cultural conditions. In particular, arabinose-negative strains grown in the presence of lactose produced very long (4- to $5-\mu \mathrm{m})$ cells that sometimes were branched and had swollen ends (Fig. 2d and h). In contrast, arabinose-positive isolates grown in the presence of lactose produced small (length, 0.4 to
$0.6 \mu \mathrm{m}$ ) coccoid cells (Fig. $2 \mathrm{~b}$ and $\mathrm{f}$ ). The morphology varied with the $\mathrm{pH}$ and with the concentration of $\mathrm{O}_{2}$ at different temperatures (Fig. 2e, g, l, and n through q). The relationship between dissolved oxygen and amount of growth for the inopinatum group strains was not determined.

Fermentative characteristics. Table 2 shows the sugar fermentation patterns of the inopinatum and denticolens groups. The fermentation patterns of the two groups were different. In particular, xylose was fermented only by strains belonging to the inopinatum group, whereas galactose and cellobiose were fermented only by strains belonging to the denticolens group. The inability of the inopinatum group strains to ferment galactose is a very unusual characteristic in the genus Bifidobacterium and is shared only by the species Bifidobacterium minimum (19). A total of 25 strains $(78 \%)$ of the inopinatum group fermented lactose, although with 10 of these strains fermentation was delayed or weak; in addition, some strains belonging to this group fermented glucose slowly. A comparison with the other 29 species of the genus (6) revealed that the fermentative characteristics of the two new groups differ markedly from the characteristics of the previously described species, mainly because strains belonging to the new groups ferment dextran (molecular weight, 10,000 to 2,000,000), an uncommon characteristic. This polymer of glucose, which can be produced from sucrose by the action of Leuconostoc mesenteroides or Streptococcus mutans, was fermented by most of the strains of the two new groups. Our results clearly show that the fermentation patterns of the two new groups differ from the fermentation pattern of $B$. dentium, which does not ferment dextran.

Other physiological and biochemical characteristics. In general, the other phenetic characteristics of the two new groups were similar to those of most bifidobacteria, as shown in the species descriptions below. There were very few differences between the two groups; the inopinatum group strains grew at somewhat higher temperatures (44 instead of $42^{\circ} \mathrm{C}$ ), and strains of both groups grew, albeit poorly, at lower $\mathrm{pH}$ values than $B$. dentium. In glucose fermentation tests all of the strains of the two new groups produced acetic acid and L- $(+)$-lactic acid. All of the isolates were anaerobes, and growth of these isolates was stimulated by the presence of $\mathrm{CO}_{2}$; no growth occurred on slants incubated under aerobic conditions.

None of the strains belonging to the inopinatum and denticolens groups grew in synthetic medium, even when all of the amino acids and vitamins were added. All of the isolates belonging to the inopinatum group and most of the strains belonging to the denticolens group grew well when the synthetic medium contained, in addition to all of the amino acids and the vitamins, pantethine $(0.15 \mathrm{~g} /$ liter $)$, pancreatin $(0.15 \mathrm{~g} /$ liter $)$, and lysozyme ( $0.4 \mathrm{~g} /$ liter, inactivated by boiling for $10 \mathrm{~min})$. Strains belonging to the inopinatum group grew poorly and strains belonging to the denticolens group did not grow when pantethine, pancreatin, and lysozyme were added one at a time, suggesting that the denticolens group strains require all three of these compounds.

Electrophoretic analysis of soluble proteins. The polyacrylamide gel electrophoresis patterns of some representative strains of the two new groups (Fig. 3) confirmed that the strains belonging to each group were closely related and that there were some minor differences within the groups, suggesting that some intraspecific subgroups could be recognized. Moreover, Fig. 3 shows that the inopinatum group is distinct from the denticolens group and that both of these groups differ from $B$. dentium.

DNA base compositions. The DNA $\mathrm{G}+\mathrm{C}$ contents of the strains belonging to the inopinatum group were $45 \pm 1 \mathrm{~mol} \%$ and thus were significantly lower than the $G+C$ contents of the 


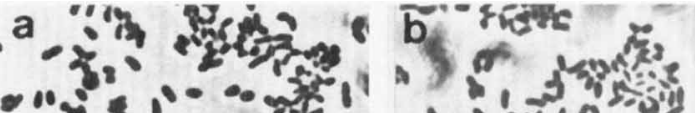

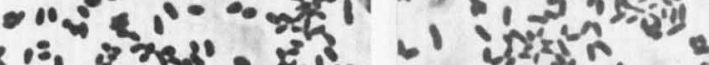

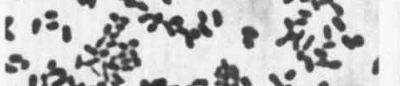
: is

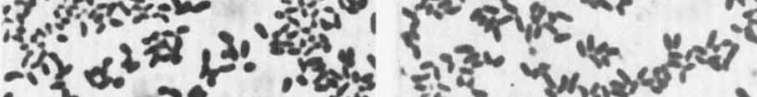

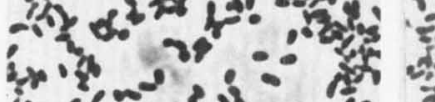
: $\because$ प्र०,

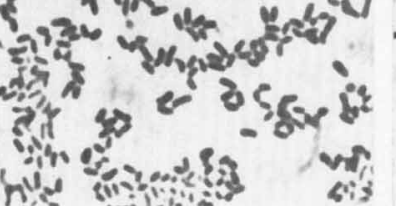

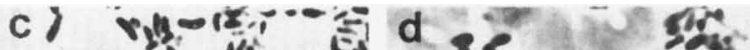

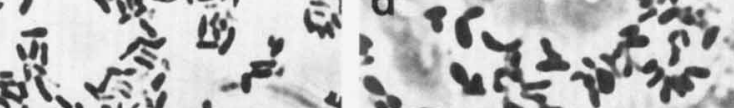
mon to

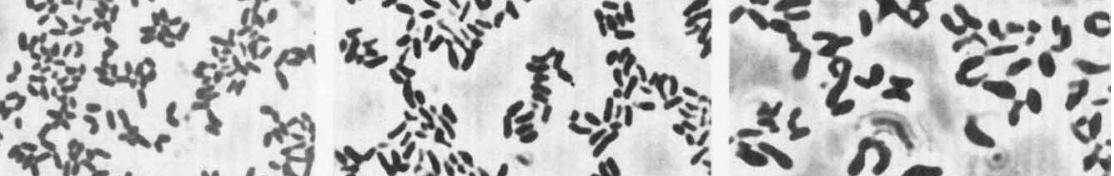

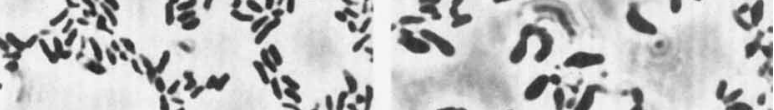

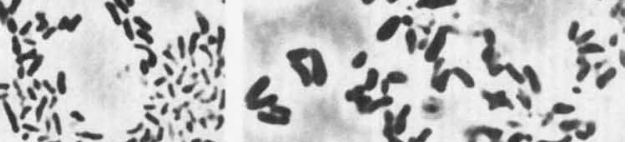

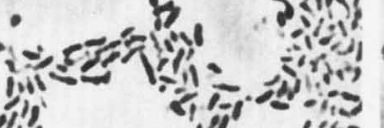
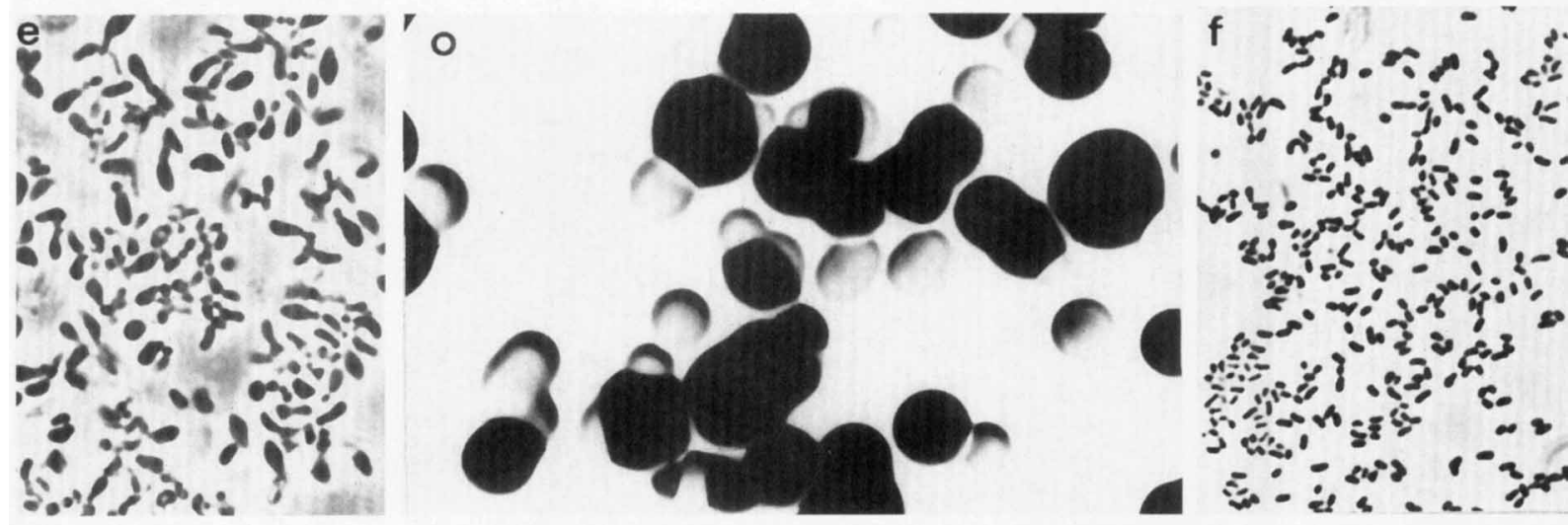

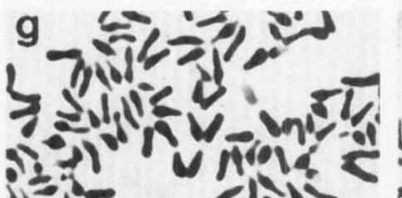

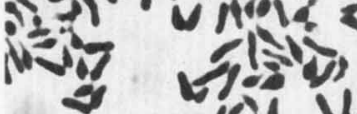

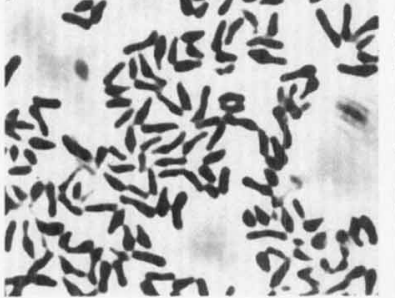
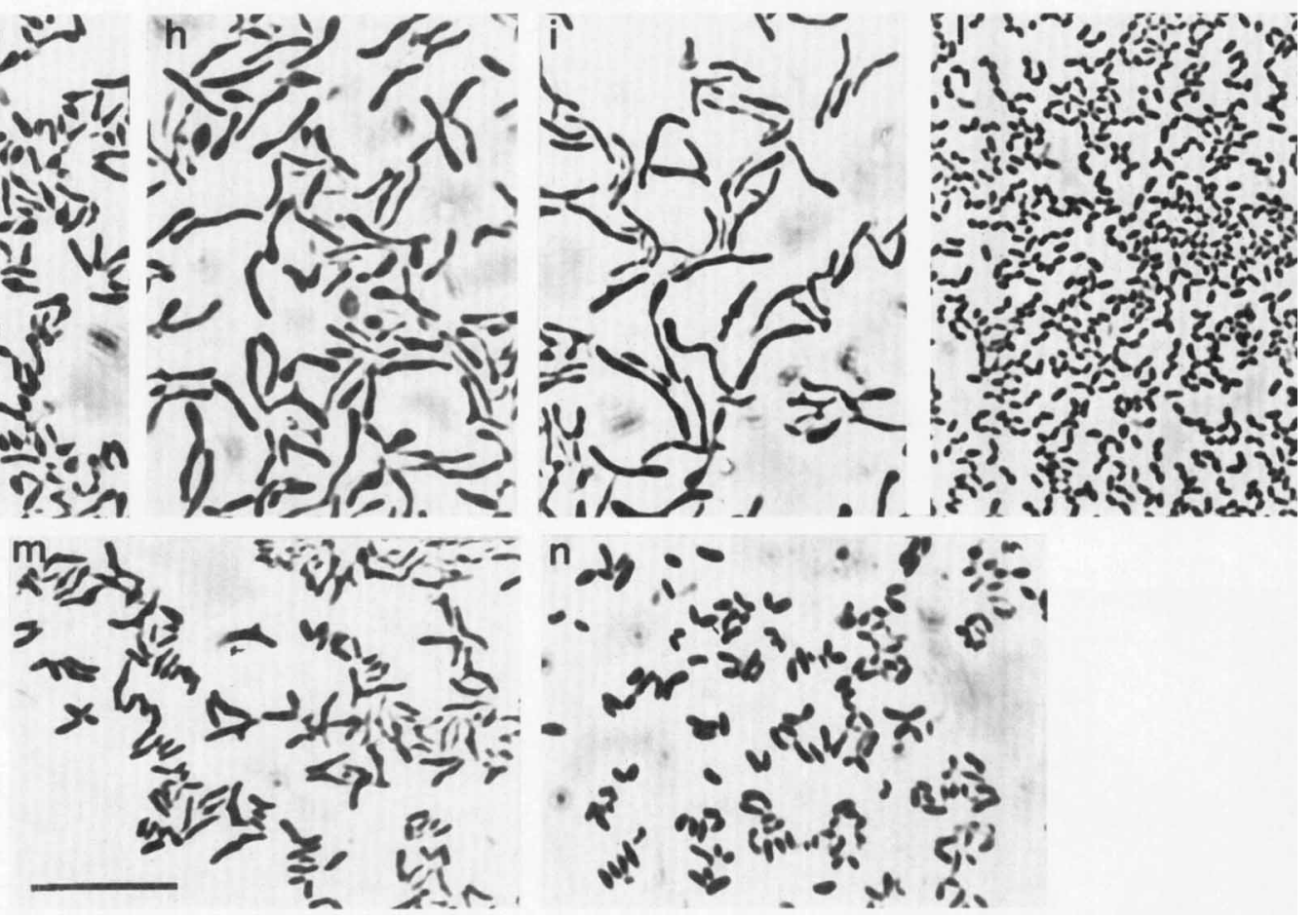

FIG, 1. Morphology of $B$. inopinatum sp. nov. (a through $\mathrm{n}$ ) Phase-contrast micrographs. Bar $=10 \mu \mathrm{m}$. (a) Strain B3109 ${ }^{\mathrm{T}}$ grown in TPY liquid medium supplemented with glucose. (b) Strain B3086 grown in TPY liquid medium supplemented with lactose. (c) Strain B3101 grown in TPY liquid medium supplemented with raffinose. (d) Strain B3086 grown in TPY liquid medium supplemented with maltose. (e) Strain B3016 grown in TPY liquid medium supplemented with starch. (f) Strain B3101 grown in TPY liquid medium supplemented with xylose. (g) Strain B3109/1 cells from an O colony on TPY agar medium supplemented with glucose. (h) Strain B3109/1 cells from an O colony in TPY liquid medium supplemented with glucose and incubated in the presence of $10 \%$ O 2 (i) Strain B3109/8 cells from a T colony in TPY liquid medium supplemented with glucose and incubated in the presence of $10 \% \mathrm{O}_{2}$. (I) Strain B3109/8 cells from a T colony on TPY agar medium supplemented with glucose. (m) Strain B3014 grown on tomato juice agar. (n) Strain B3109 ${ }^{\mathrm{T}}$ grown in Mann-Rogosa-Sharpe liquid medium. (o) T and O colonies of strain B3080 on a plate. 


\section{ances 3. (ब)} 等,

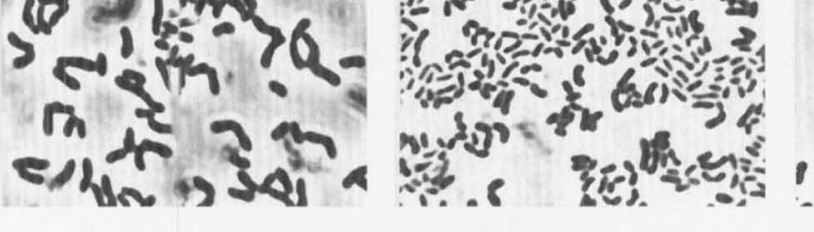

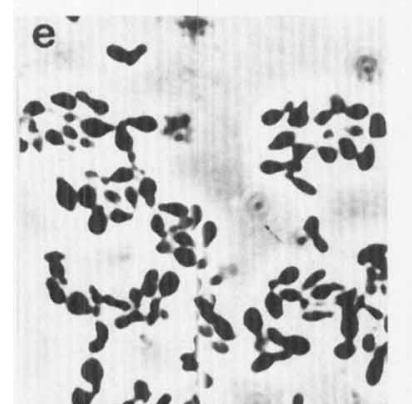

8.

\begin{abstract}
icis
\end{abstract}
1. 090 ,

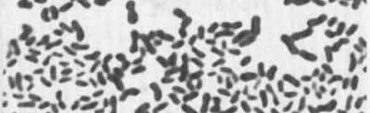

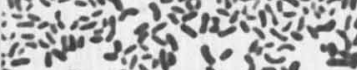
i.

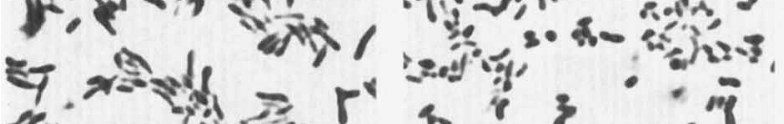

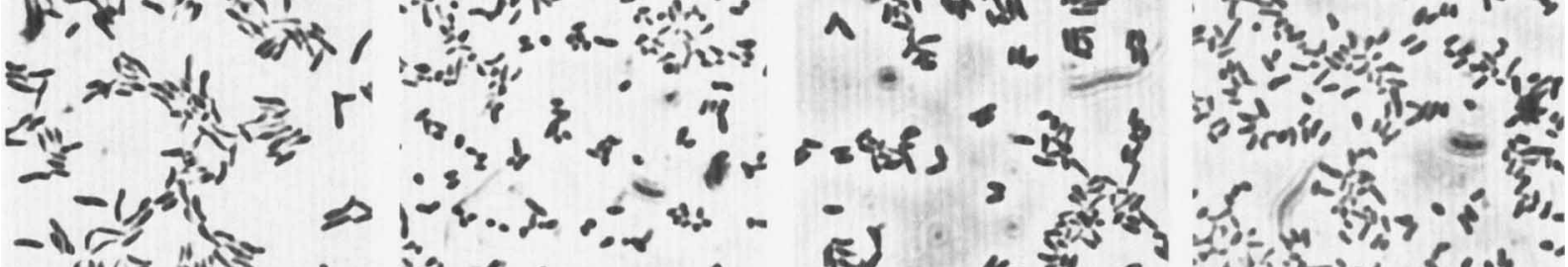

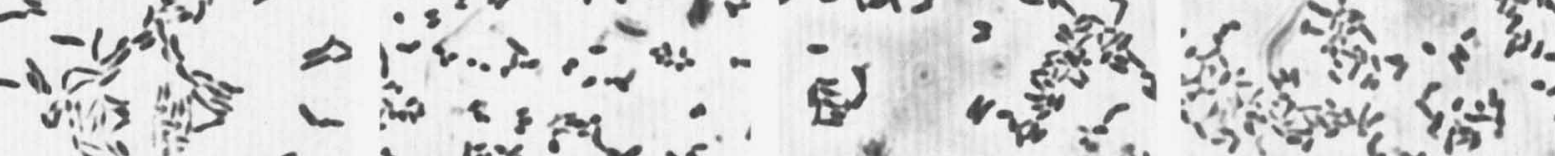
捗,
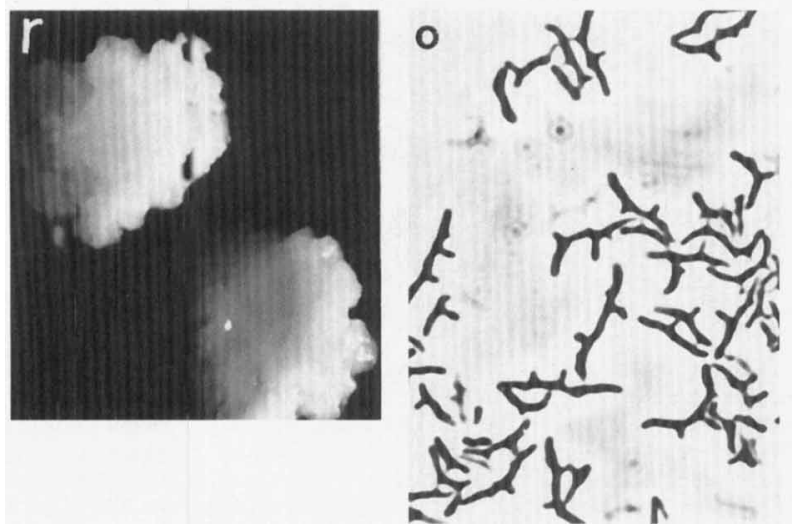

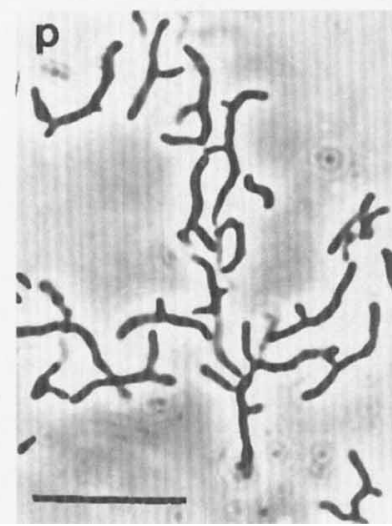

$x^{2}$

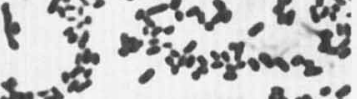

सित्र रहै।

$i=\frac{1}{2}$

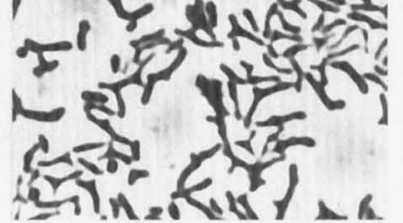

2.

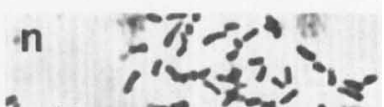

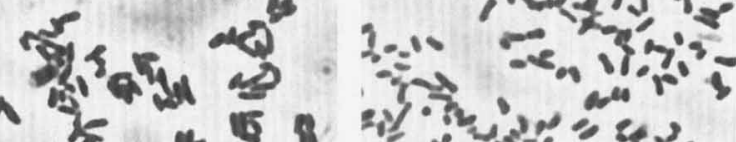

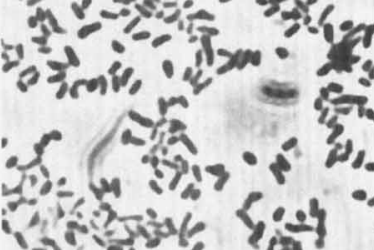
H.1 का $6 x$ ar

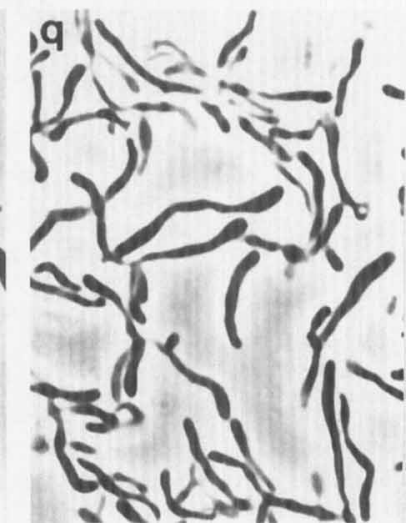


FIG. 2. Morphology of $B$. denticolens sp. nov. (a through q) Phase-contrast micrographs. Bar $=10 \mu \mathrm{m}$. (a) Strain B3028 ${ }^{\mathrm{T}}$ grown in TPY liquid medium supplemented with glucose. (b) Strain B $3028^{\mathrm{T}}$ grown in TPY liquid medium supplemented with lactose. (c) Strain B3088 grown in TPY liquid medium supplemented with glucose. (d) Strain B3088 grown in TPY liquid medium supplemented with lactose. (e) Strain B3032 grown in TPY liquid medium supplemented with glucose at an initial pH of 5.5. (f) Strain B3032 cells from a colony on TPY agar supplemented with lactose. (g) Strain B3087 grown in TPY liquid medium supplemented with glucose at an initial $\mathrm{pH}$ of 4.9. (h) Strain B3088 cells from a colony on TPY agar supplemented with lactose. (i) Strain B3028 ${ }^{\mathrm{T}}$ grown in TPY liquid medium supplemented with glucose at an initial pH of 6.7. (1) Strain B3032 grown in TPY liquid medium supplemented with glucose at an initial pH of 7.7. (m) Strain B3087 grown in TPY liquid medium supplemented with glucose at an initial $\mathrm{pH}$ of 6.5 . (n) Strain B3087 grown in TPY liquid medium supplemented with glucose at an initial $\mathrm{pH}$ of 8.0. (o) Strain B3047 grown in TPY liquid medium supplemented with glucose incubated at $30^{\circ} \mathrm{C}$ in the presence of $10 \%$ O liquid medium supplemented with glucose incubated at $30^{\circ} \mathrm{C}$ in the presence of $10 \% \mathrm{O}_{2}$. (q) Strain B3090 grown in TPY liquid medium supplemented with glucose incubated at $42^{\circ} \mathrm{C}$ in the presence $10 \% \mathrm{O}_{2}$. (r) Colonies of strain $\mathrm{B} 3028^{\mathrm{T}}$ on a plate.

previously described species of the genus Bifidobacterium (55 to $67 \mathrm{~mol} \%$ ) (19). In contrast, the strains belonging to the denticolens group had $\mathrm{G}+\mathrm{C}$ contents of $55 \pm 1 \mathrm{~mol} \%$, which are within the $\mathrm{G}+\mathrm{C}$ content range of the genus.

DNA relatedness. Table 3 shows the high levels of DNA homogeneity of the strains belonging to the inopinatum and denticolens groups, as well as the low levels of relatedness between the DNAs of the strains belonging to the two new groups and the DNA of type strain B764 of $B$. dentium, the other Bifidobacterium species isolated from dental caries. In addition, dextran-negative isolates B3087 and B3014 of the denticolens and inopinatum groups, respectively, also exhibited high levels of DNA relatedness with dextran-positive strains, which confirmed that they belonged to their respective groups. The DNA relatedness values shown in Table 4 demonstrate that the inopinatum and denticolens groups are genetically distinct from the 28 previously described Bifidobacterium species.

Similarities in the characteristics of the inopinatum group and Gardnerella vaginalis (similarities in cell morphology and DNA base composition), as well as the high level of rRNA relatedness of the genera Bifidobacterium and Gardnerella determined in the study of Olsen et al. (16), suggested that we should perform a DNA-DNA hybridization experiment with members of the two taxa. A level of reassociation of less than $10 \%$ was found, which showed that these two taxa are genetically distinct.

Plasmids. The strains belonging to the inopinatum and denticolens groups did not contain plasmid DNA or produce any band in addition to the chromosomal DNA bands.

The genetic distinctness of the inopinatum group from the denticolens group and from the other Bifidobacterium species was reflected in its unusual phenotypic characteristics, such as its cellular morphology, a characteristic that has significance in this group, and the presence of two types of colonies associated with different cellular morphologies. The latter characteristic, which so far has been observed and studied as a phenomenon of phase variation only in Bifidobacterium animalis (2) among the previously described bifidobacteria, must still be identified as such in the inopinatum group. The other phenotypic characteristic which distinguishes both new groups from other bifidobacteria is the ability to ferment dextran, which is not fermented by the previously described bifidobacteria (6). This characteristic was observed by Clarke (5) in a rumen strain which closely resembled bifidobacteria and was therefore named Lactobacillus bifidus. Later, Kaster and Brown (11) isolated from human dental plaque three dextran-degrading, fructose-6-phosphate phosphoketolase-positive strains; these authors placed these three strains in the genus Bifidobacterium but not in any species because they did not appear to be members of $B$. dentium. Another characteristic of the inopinatum group strains is their low DNA G $+\mathrm{C}$ contents $(45 \pm 1 \mathrm{~mol} \%)$; this characteristic is not shared by any other Bifidobacterium species. The hypothesis that this group of strains belongs to the genus Bifidobacterium is supported by the presence of fructose6-phosphate phosphoketolase, the key enzyme of the glucose catabolic pathway in bifidobacteria, by the production of lactic and acetic acids as end products of glucose metabolism, and by the typical bifidobacterial morphology, which occurs in the cells of $\mathrm{O}$ colonies and when the isolates are grown in the presence of traces of $\mathrm{O}_{2}$ or different carbon sources. On the basis of our results, the strains belonging to the denticolens group were considered members of the genus Bifidobacterium because they had a cellular morphology and $\mathrm{G}+\mathrm{C}$ contents similar to those of the other species of the genus. However, the ability of most of the isolates to ferment dextran (which is uncommon) and the lack of genomic relatedness between these strains and the previously described Bifidobacterium species suggest that the denticolens group can also be differentiated from the previously described bifidobacteria. Our data show that the inopinatum and denticolens groups represent two distinct species, for which we propose the names Bifidobacterium inopinatum and Bifidobacterium denticolens, respectively.

Description of Bifidobacterium inopinatum sp. nov. Bifidobacterium inopinatum (in.o. pin.a' tum. L. neut. adj. inopinatum, unexpected, referring to the very unusual morphology). Cells are gram positive and nonmotile, do not form spores, are very small and coccoid, and occur singly or in pairs; the cells are 0.3 to $0.6 \mu \mathrm{m}$ long. When strains in liquid cultures ferment sugars, such as lactose or raffinose, the cells become longer and more slender, while in the presence of maltose and starch, the cells are much longer and larger with swellings (length, 1.3 to 3.0 $\mu \mathrm{m}$ ) (this occurs also on Mann-Rogosa-Sharpe medium and tomato juice agar). The homogeneous sediment can be dispersed easily and is never in clumps.

Colonies on TPY agar are circular, soft, smooth, convex with unbroken edges, and cream to white. There are two types of

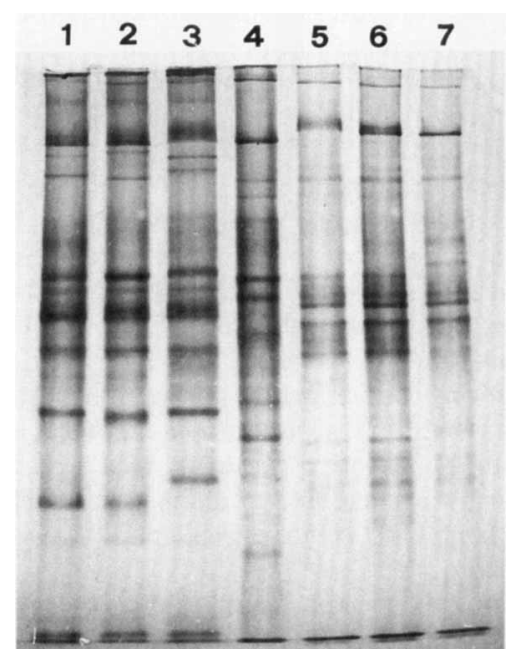

FIG. 3. Electrophoretic patterns of seven strains of three Bifidobacterium species isolated from dental caries. Lanes 1 to $3, B$. inopinatum; lane $4, B$. dentium; lanes 5 to $7, B$. denticolens. 
TABLE 3. Levels of DNA relatedness between $B$. denticolens and $B$. inopinatum strains, as determined with isolates obtained from different specimens, and levels of DNA relatedness between the two new species and $B$. dentium, the other species found in dental caries

\begin{tabular}{|c|c|c|c|}
\hline \multirow{2}{*}{$\begin{array}{c}\text { Source of } \\
\text { competitor DNA }\end{array}$} & \multicolumn{3}{|c|}{$\begin{array}{l}\text { \% Complementarity to } \\
\text { reference DNA from: }\end{array}$} \\
\hline & $\begin{array}{l}\text { B. denticolens } \\
\text { B3028 }\end{array}$ & $\begin{array}{l}\text { B. inopinatum } \\
{\text { B3 } 3109^{\mathrm{T}}}\end{array}$ & $\begin{array}{l}\text { B. dentium } \\
{\mathrm{B} 764^{\mathrm{T}}}^{\mathrm{m}}\end{array}$ \\
\hline \multicolumn{4}{|l|}{ B. denticolens strains } \\
\hline $\mathrm{B} 3028^{\mathrm{T}}\left(=\right.$ DSM $\left.10105^{\mathrm{T}}\right)$ & 100 & 10 & 9 \\
\hline B3006 & 112 & 7 & 10 \\
\hline B3047 & 78 & 5 & 12 \\
\hline B3087 & 81 & 17 & 3 \\
\hline B3107 & 115 & 3 & 7 \\
\hline Range & $78-115$ & $3-17$ & $3-12$ \\
\hline \multicolumn{4}{|l|}{ B. inopinatum strains } \\
\hline $\mathrm{B} 3109^{\mathrm{T}}\left(=\mathrm{DSM} 10107^{\mathrm{T}}\right)$ & 25 & 100 & 7 \\
\hline B3002 & 7 & 75 & 2 \\
\hline B3010 & 12 & 108 & 5 \\
\hline B3014 & 15 & 82 & 3 \\
\hline B3055 & 9 & 97 & 10 \\
\hline B3082 & 6 & 76 & 9 \\
\hline B3094 & 10 & 98 & 3 \\
\hline Range & $7-25$ & $75-108$ & $2-10$ \\
\hline
\end{tabular}

colonies, $\mathrm{T}$ colonies and $\mathrm{O}$ colonies. The $\mathrm{T}$ colonies are made up of cells having a species-specific shape, and the $O$ colonies are made up of longer, slightly irregular rods and rarely contain club-shaped cells. When liquid cultures are incubated in air- $\mathrm{CO}_{2}(1: 10)$, the cells obtained from $\mathrm{O}$ and $\mathrm{T}$ colonies are much longer and more flexuous with wider ends and rare branches (length, 2.0 to $8.0 \mu \mathrm{m}$ ); these cells are very similar to the cells of typical bifidobacteria.

Anaerobic. $\mathrm{CO}_{2}$ enhances anaerobic growth.

The optimum temperature for growth is 38.5 to $42^{\circ} \mathrm{C}$, the minimum temperature is 27 to $30.5^{\circ} \mathrm{C}$, and the maximum temperature is $44^{\circ} \mathrm{C}$. No growth occurs at 26.5 or $46^{\circ} \mathrm{C}$.

The optimum initial $\mathrm{pH}$ is 6.9 to 7.4 , growth is delayed at $\mathrm{pH}$ 4.9 or 8.0 , and no growth occurs at $\mathrm{pH} 4.3$ or 8.5 . D-Xylose, D-ribose, glucose, fructose, sucrose, maltose, dextrin, starch, amylose, and amylopectin are fermented. L-Arabinose, D-glucosamine, L-rhamnose, mannose, $\alpha$-D-galacturonate, D-fucose, L-fucose, D-galactosamine, trehalose, cellobiose, gluconate, lactate, xylan, polygalacturonate, alginate, arabinogalactan, pectin, laminarin, D-mannitol, D-glucitol, glycerol, hyaluronate, heparin, chondroitin sulfate, ovomucoid, bovine submaxillary mucin, porcine gastric mucin, gum arabic, gum ghatti, gum guar, gum locust bean, gum karaya, and gum tragacanth are not fermented. Galactose is characteristically not fermented by this species. Fermentation of melibiose, lactose, salicin, D-glucuronate, melezitose, raffinose, and inulin is variable. Only 1 of 31 strains does not ferment dextran.

Produces acetylmethylcarbinol and hydrolyzes asparagine. Nitrate reduction, indole, hydrogen sulfide, and catalase or pseudocatalase (hemin) production negative. Gelatin is not liquefied; ammonia is not produced from urea or arginine. Litmus milk is always acidified and coagulated. The fermentation products from glucose are $\mathrm{L}-(+)$ lactic acid and acetic acid at a molar ratio of 1:2.9.

The DNA of this species is not related to the DNA of $B$. denticolens or the DNA of any other species of the genus Bifidobacterium. The $\mathrm{G}+\mathrm{C}$ content of the DNA is $45 \pm 1$ mol\% (as determined by the thermal denaturation method).

Found in human dental caries.
The type strain is strain B3109 (= DSM 10107).

Description of Bifidobacterium denticolens sp. nov. Bifidobacterium denticolens (den.ti.co' lens. L. masc. n. dens, dentis, tooth; L. v. colere, to dwell; L. pres. part. colens, dwelling; M.L. adj. denticolens, tooth dwelling). Gram-positive, nonmotile, non-spore-forming, small, slender rods that occasionally are arranged in a $\mathrm{V}$ shape are 0.8 to $1.5 \mu \mathrm{m}$ long. Morphology is variable depending on the cultural conditions. In the presence of lactose, the cells of arabinose-negative strains are very long (4 to $5 \mu \mathrm{m}$ ), sometimes branched, and have wide ends; the cells of arabinose-positive strains are smaller and coccoid (length, 0.4 to $0.6 \mu \mathrm{m})$. At an initial $\mathrm{pH}$ of 7.7 or 8.0 the cells are very small (length, 0.4 to $0.6 \mu \mathrm{m}$ ); at an initial $\mathrm{pH}$ of 4.9 or 5.5 the cells are longer and branched or short (length, 0.8 to $2.5 \mu \mathrm{m}$ ) and frequently club shaped. In liquid cultures incubated in air- $\mathrm{CO}_{2}(1: 10)$ at $37^{\circ} \mathrm{C}$ the cells are much longer rods with swollen ends; however, the cells become very long (length, 3 to $10 \mu \mathrm{m})$ and branched when cultures are incubated at $30^{\circ} \mathrm{C}$, whereas the cells are unbranched and flexuous with protuberances if they are grown at $42^{\circ} \mathrm{C}$. Liquid cultures of this species always have clear supernatants with compact sediment in clumps that cannot be dispersed with vigorous swirling.

Colonies on TPY agar are soft, smooth, circular, convex with irregular margins, glistening, and cream to white.

Anaerobic. $\mathrm{CO}_{2}$ enhances anaerobic growth.

The optimum temperature for growth is 36.5 to $38.5^{\circ} \mathrm{C}$, the minimum temperature is 27.0 to $30.5^{\circ} \mathrm{C}$, and the maximum temperature is 42 to $44^{\circ} \mathrm{C}$. No growth occurs at 25 or $46^{\circ} \mathrm{C}$.

TABLE 4. Levels of DNA relatedness between previously described Bifidobacterium species and the type strains of the new species

\begin{tabular}{|c|c|c|}
\hline \multirow{2}{*}{$\begin{array}{c}\text { Source of } \\
\text { competitor DNA }\end{array}$} & \multicolumn{2}{|c|}{$\begin{array}{l}\text { \% Reassociation with } \\
\text { reference DNA from: }\end{array}$} \\
\hline & $\begin{array}{l}\text { B. denticolens } \\
\text { B3028 }\end{array}$ & $\begin{array}{l}\text { B. inopinatum } \\
\mathrm{B} 3109^{\mathrm{T}}\end{array}$ \\
\hline B. adolescentis $\mathrm{E} 194 \mathrm{a}^{\mathrm{T}}$ & 11 & 7 \\
\hline$B$. angulatum $\mathrm{B} 677^{\mathrm{T}}$ & 3 & 7 \\
\hline B. animalis R $101-8^{\mathrm{T}}$ & 8 & 5 \\
\hline B. asteroides $\mathrm{C} 51^{\mathrm{T}}$ & 5 & 6 \\
\hline B. bifidum $\mathrm{Ti}^{\mathrm{T}}$ & 7 & 9 \\
\hline B. boum Ru $917^{\mathrm{T}}$ & 4 & 5 \\
\hline B. breve $\mathrm{S} 1^{\mathrm{T}}$ & 15 & 4 \\
\hline B. catenulatum B669 & 8 & 21 \\
\hline B. choerinum Su $806^{\mathrm{T}}$ & 9 & 10 \\
\hline B. coryneforme $\mathrm{C} 215^{\mathrm{T}}$ & 7 & 4 \\
\hline B. cuniculi Ra $93^{\mathrm{T}}$ & 10 & 9 \\
\hline B. dentium B764 ${ }^{\mathrm{T}}$ & 9 & 7 \\
\hline B. gallicum $\mathrm{P}^{\mathrm{T}}$ & 12 & 10 \\
\hline B. gallinarum $\mathrm{CH} 206-5^{\mathrm{T}}$ & 7 & 12 \\
\hline B. globosum Ru $230^{\mathrm{T}}$ & 8 & 17 \\
\hline B. indicum $\mathrm{C} 410^{\mathrm{T}}$ & 15 & 12 \\
\hline B. infantis $\mathrm{S} 12^{\mathrm{T}}$ & 3 & 9 \\
\hline B. longum E194 $\mathrm{b}^{\mathrm{T}}$ & 7 & 10 \\
\hline B. magnum $\mathrm{Ra}^{\mathrm{T}}$ & 12 & 14 \\
\hline B. merycicum Ru915B ${ }^{\mathbf{T}}$ & 7 & 11 \\
\hline B. minimum $\mathrm{F} 392^{\mathrm{T}}$ & 5 & 4 \\
\hline B. pseudocatenulatum $\mathrm{B} 1279^{\mathrm{T}}$ & 18 & 15 \\
\hline B. pseudolongum PNC-2-9G ${ }^{\mathrm{T}}$ & 11 & 8 \\
\hline B. pullorum $\mathrm{P} 145^{\mathrm{T}}$ & 8 & 12 \\
\hline B. ruminantium $\mathrm{Ru} 687^{\mathrm{T}}$ & 5 & 9 \\
\hline B. saeculare $\mathrm{Ra} 161^{\mathrm{T}}$ & 13 & 4 \\
\hline B. subtile $\mathrm{F} 395^{\mathrm{T}}$ & 10 & 11 \\
\hline B. suis $\mathrm{Su} 859^{\mathrm{T}}$ & 9 & 10 \\
\hline B. thermophilum $\mathrm{P} 2-91^{\mathrm{T}}$ & 7 & 11 \\
\hline B. denticolens $\mathrm{B} 3028^{\mathrm{T}}$ & 100 & 10 \\
\hline B. inopinatum $\mathrm{B} 3109^{\mathrm{T}}$ & 25 & 100 \\
\hline
\end{tabular}


The optimum initial $\mathrm{pH}$ is 6.7 to 7.3 , growth is delayed at $\mathrm{pH}$ 4.9 or 8.0 , and no growth occurs at $\mathrm{pH} 4.4$ or 8.5 .

D-Ribose, galactose, glucose, fructose, lactose, cellobiose, sucrose, maltose, melibiose, raffinose, dextrin, starch, amylose, amylopectin, inulin, and salicin are fermented. D-Xylose, Dglucuronate, L-rhamnose, mannose, $\alpha$-D-galacturonate, D-fucose, L-fucose, D-galactosamine, melezitose, gluconate, lactate, xylan, polygalacturonate, alginate, arabinogalactan, pectin, laminarin, D-mannitol, D-glucitol, glycerol, hyaluronate, heparin, chondroitin sulfate, ovomucoid, bovine submaxillary mucin, porcine gastric mucin, gum arabic, gum ghatti, gum guar, gum locust bean, gum karaya, and gum tragacanth are not fermented. Fermentation of L-arabinose, D-glucosamine, and trehalose is variable. Dextran is fermented by $75 \%$ of the strains.

Produces acetylmethylcarbinol and hydrolyzes asparagine. Nitrate reduction, indole, hydrogen sulfide, and catalase or pseudocatalase (hemin) production negative. Gelatin is not liquefied; ammonia is not produced from urea or arginine. Litmus milk is always acidified and coagulated.

The fermentation products from glucose are $\mathrm{L}-(+)$-lactic acid and acetic acid at a molar ratio of 1:2.

The DNA of this species is not related to the DNA of $B$. inopinatum or the DNA of any other species of the genus Bifidobacterium.

The $\mathrm{G}+\mathrm{C}$ content of the DNA is $55 \pm 1 \mathrm{~mol} \%$ (as determined by the thermal denaturation method).

Found in human dental caries.

The type strain is strain B3028 (:= DSM 10105).

\section{ACKNOWLEDGMENTS}

We thank Alfredo Pacini for providing the human dental caries specimens. The excellent technical assistance of L. Masi-Guiduzzi in the photo documentation is gratefully acknowledged.

This research was supported by National Research Council of Italy special project RAISA, sub-project 4, paper 2376.

\section{REFERENCES}

1. Beerens, H., A. Gérard, and J. Guillaume. 1957. E'tude de 30 souches de Bifidobacterium bifidum (Lactobacillus bifidus). Caractérisation d'une variété buccale. Comparaison avec les souches d'origine fécale. Ann. Inst. Pasteur Lille 9:77-85.

2. Biavati, B., F. Crociani, P. Mattarelli, and V. Scardovi. 1992. Phase variations in Bifidobacterium animalis. Curr. Microbiol. 25:51-55.

3. Biavati, B., V. Scardovi, and W. E. C. Moore. 1982. Electrophoretic patterns of proteins in the genus Bifidobacterium and proposal of four new species. Int. J. Syst. Bacteriol. 32:358-373.

4. Brailowsky-Lounkewitch, Z. A. 1915. Contribution à l'étude de la flore mi- crobienne habituelle de la bouche normale (nouveau-nés, enfants, adultes). Ann. Inst. Pasteur (Paris) 29:379-404.

5. Clarke, R. T. J. 1959. A dextran-fermenting organism from the rumen closely resembling Lactobacillus bifidus. J. Gen. Microbiol. 20:549-553.

6. Crociani, F., A. Alessandrini, M. Mucci, and B. Biavati. 1994. Degradation of complex carbohydrates by Bifidobacterium spp. Int. J. Food Microbiol. 24: 199-210.

7. De Vries, W., and A. H. Stouthamer. 1968. Fermentation of glucose, lactose, galactose, mannitol, and xylose by bifidobacteria. J. Bacteriol. 96:472-478.

8. Georg, L. K., G. W. Robertstad, S. A. Brinkman, and M. D. Hicklin. 1965. A new pathogenic anaerobic Actinomyces species. J. Infect. Dis. 115:88-99.

9. Holdeman, L. V., E. P. Cato, and W. E. C. Moore. 1977. Anaerobe laboratory manual, 4th ed. Virginia Polytechnic Institute and State University, Blacksburg.

10. Holdeman, L. V., and W. E. C. Moore (ed.). 1970. Outline of clinical methods in anaerobic bacteriology, 2 nd revision. Anaerobe Laboratory, Virginia Polytechnic Institute and State University, Blacksburg.

11. Kaster, A. G., and L. R. Brown. 1983. Extracellular dextranase activity produced by human oral strains of the genus Bifidobacterium. Infect. Immun. 42:716-720.

12. Kolenbrander, P. E., and B. L. Williams. 1981. Lactose-reversible coaggregation between oral actinomycetes and Streptococcus sanguis. Infect. Immun. 33:95.

13. Maeda, N. 1980. Anaerobic, Gram-positive, pleomorphic rods in human gingival crevice. Bull. Tokyo Med. Dent. Univ. 27:63.

14. Marmur, J. 1961. A procedure for the isolation of deoxyribonucleic acids. J. Mol. Biol. 3:208-218.

15. Müller, H., and H. Pech. 1967. Bifidus bakterien bei der Frau. Arch. Gynaekol. 205:39-58.

16. Olsen, G. J., C. R. Woese, and R. Overbeek. 1994. The winds of (evolutionary) change: breathing new life into microbiology. J. Bacteriol. 176:1-6.

17. Oppenheimer, C. H., and W. A. Drost-Hansen. 1960. A relationship between multiple temperature optima for biological systems and the properties of water. J. Bacteriol. 80:21.

18. Sanyal, B., and C. Russel. 1978. Nonsporing, anaerobic, gram-positive rods in saliva and the gingival crevice of humans. Appl. Environ. Microbiol. 35: 670-678.

19. Scardovi, V. 1986. Genus Bifidobacterium Orla-Jensen, p. 1418-1434. In P. H. A. Sneath, N. S. Mair, M. E. Sharpe, and J. G. Holt (ed.), Bergey's manual of systematic bacteriology, vol. 2. Williams and Wilkins, Baltimore.

20. Scardovi, V., and F. Crociani. 1974. Bifidobacterium catenulatum, Bifidobacterium dentium, and Bifidobacterium angulatum: three new species and their deoxyribonucleic acid homology relationships. Int. J. Syst. Bacteriol. 24: 6-20.

21. Scardovi, V., and L. D. Trovatelli. 1965. The fructose-6-phosphate shunt as peculiar pattern of hexose degradation in the genus Bifidobacterium. Ann. Microbiol. Enzimol. 15:19-29.

22. Scardovi, V., and L. D. Trovatelli. 1969. New species of bifidobacteria from Apis mellifera L. and Apis indica F. A contribution to the taxonomy and biochemistry of the genus Bifidobacterium. Zentralbl. Bakteriol. Parasitenkd. Infektionskr. Hyg. Abt. 2 123:64-88.

23. Schramm, M., V. Klybas, and F. Racker. 1958. Phosphorolytic cleavage of fructose-6-phosphate by fructose-6-phosphate phosphoketolase from Acetobacter xylinum. J. Biol. Chem. 233:1283-1288.

24. Sgorbati, B., V. Scardovi, and D. J. Leblanc. 1982. Plasmids in the genus Bifidobacterium. J. Gen. Microbiol. 128:2121-2131.

25. Skerman, V. B. D., V. McGowan, and P. H. A. Sneath (ed.). 1980. Approved lists of bacterial names. Int. J. Syst. Bacteriol. 30:225-420. 